\title{
Program Pengembangan Kompetensi Sumber Daya Manusia Bidang Akuntansi dan Perpajakan PT Quantum Edukasindo Paradigma
}

\author{
Rossalina Christanti $^{\# 1}$ \\ \#Jurusan Akuntansi,Universitas Kristen Duta Wacana \\ Jl. Dr. Wahidin Sudirohusodo 5-25, Yogyakarta \\ ${ }^{1}$ rchristanti@staff.ukdw.ac.id
}

\begin{abstract}
Abstrak - Kompetensi pembukuan dan perpajakan merupakan hal yang penting dimiliki oleh staf UMKM, walaupun dengan segala keterbatasan pendanaan dari perusahaan yang skalanya masih pada mikro, kecil, atau menengah. Tujuan program pengabdian kepada masyarakat ini adalah meningkatkan kompetensi sumber daya manusia PT Quantum Edukasindo Paradigma (PT QEP), perusahaan jasa yang bergerak di bidang tes IQ online, tes minat bakat, konsultasi penjurusan studi, asesmen \& tes psikodiagnostik, konsultasi promosi jabatan, pelatihan dan bimbingan karir, serta pelatihan dan pengembangan SDM. Metode pelaksanan program PkM ini adalah participatory development, yaitu memosisikan dosen pengabdi sebagai fasilitator dan pendamping institusi mitra. Program peningkatan kompetensi SDM diawali dengan memberikan tutorial mengenai pembukuan dan penyusunan laporan keuangan. Setelah itu, program PkM dilanjutkan dengan pendampingan intensif dalam menyusun pembukuan aktual perusahaan secara rutin. Hasil dari pendampingan ini adalah peningkatan kemandirian staf keuangan PT QEP dalam menyusun pembukuan akuntansi.
\end{abstract}

Kata kunci-participary development, peningkatan kompetensi pembukuan, akuntansi UMKM.

Abstract - Bookkeeping and taxation competence is important for SME staff, despite all of the company's limited budget. The purpose of this community development program is to improve the competence of human resources at PT Quantum Edukasindo Paradigma (PT QEP), a service company engaged in online IQ tests, talent interest tests, study major consultations, psychodiagnostics assessments, job promotion consultations, training and career guidance, as well as human resource training and development. Method conducted in this community development program is participatory development, where lecturer positioned as mentor to the company. The human resource development program began by giving tutorials on bookkeeping and financial statement preparation, then followed by intensive assistantship in working up company's actual bookkeeping on a regular basis.
Result of this community development program is employee's competence enhancement in preparing accounting bookeeping.

Keywords - participatory development, bookkeeping competency, SME staff competence.

\section{Pendahuluan}

PT Quantum Edukasindo Paradigma (yang selanjutnya disingkat QEP) merupakan perusahaan yang tergolong dalam kategori usaha mikro, kecil, dan menengah. QEP berlokasi di Jl. Sumatera Gg. Bintan E-105A, Kaliurang, Km.6,5, Kabupaten Sleman, Provinsi Daerah Istimewa Yogyakarta. PT QEP merupakan perusahaan jasa yang didirikan pada tahun 2000 dan pada tahun 2016, QEP resmi berubah bentuk menjadi berbadan hukum PT. Jika ditinjau dari segi jumlah penghasilan bruto setahun, perusahaan ini tergolong jenis UMKM. Penentuan golongan ini didasarkan dari rentang jumlah penghasilan yang ditentukan Direktorat Jenderal Pajak, yaitu usaha dengan omset bruto kurang dari 4,8 milyar dalam setahun.

Jasa yang diberikan oleh QEP adalah tes IQ Online, tes minat bakat, konsultasi penjurusan studi, asesmen \& tes psikodiagnostik, konsultasi promosi jabatan, pelatihan dan bimbingan karir, serta pelatihan dan pengembangan SDM. QEP merupakan perusahaan jasa yang bermitra dengan sekolah, lembaga pendidikan, instansi pemerintah, maupun perusahaan multinasional dengan visi-misi untuk membina, memperlengkapi, dan mempersiapkan sumber daya manusia Indonesia agar dapat memberi kontribusi positif dalam keluarga, pelayanan, organisasi, serta menjadi aset bangsa yang tinggi iman, tinggi ilmu, tinggi karakter, sesuai dengan visi dan misi PT QEP.

Karyawan tetap PT QEP mencakup direksi beserta staf administrasi, sedangkan karyawan tidak tetap PT QEP mencakup trainer dan assessor yang sifatnya paruh waktu 
atau freelance. Hal ini dapat dimaklumi mengingat PT QEP merupakan perusahaan yang bergerak di bidang jasa training dan tes psikodiagnostika, sehingga sistem pembagian tugas dan metode penilaian kinerja dapat diprediksi dan dikelola berdasarkan pesanan yang masuk.

Permasalahan umum yang dihadapi oleh industri dengan skala mikro, kecil, dan menengah adalah keterbatasan kapasitas sumber daya manusia [1], [2]. Hal ini dapat dilihat dari kurang adanya pemisahan tugas yang jelas akibat keterbatasan personel [3]. Satu karyawan diharapkan dapat mengerjakan beberapa tugas/job description sekaligus untuk meminimalkan biaya dan meningkatkan efektifitas operasional. Jika dilihat dari omset bruto, efisiensi sumber daya manusia merupakan strategi yang paling memungkinkan bagi perusahaan skala mikro, kecil, dan menengah, walaupun dapat berdampak pada reliabilitas dan kredibilitas outcome yang dihasilkan perusahaan.

Spesifik dalam bidang akuntansi, keuangan, dan perpajakan, keterbatasan sumber daya manusia pada perusahaan skala mikro, kecil, dan menengah berakibat pada tugas yang dirangkap oleh satu personel. Personel yang bertugas dalam bidang produksi bisa merangkap sebagai personel akuntansi dan keuangan. Personel akuntansi dan keuangan bisa merangkap sebagai personel pemasaran dan penjualan. Bahkan, pemilik atau direktur dapat merangkap tugas bagian keuangan. Berdasarkan contoh-contoh tersebut, rangkap tugas masih memungkinkan dilakukan karena beban kerja atau workload perusahaan skala mikro, kecil, menengah belum sebesar perusahaan yang sudah mature.

Perspektif lain yang dapat dijadikan rasionalisasi permasalahan umum yang dialami sebagian besar UMKM adalah terkait dengan akuntabilitas publik. UMKM entitas tanpa akuntabilitas publik yang signifikan, sebagaimana didefinisikan dalam Standar Akuntansi Keuangan Entitas Tanpa Akuntabilitas Publik (SAK ETAP). Tidak diperlukannya akuntabilitas publik serta ruang lingkup pemangku kepentingan (stakeholder) yang masih kecil menyebabkan urgensi untuk membuat sistem pembukuan dan pelaporan keuangan yang terstruktur menjadi minim. Perspektif ini menggiring pada permasalahan umum yang kedua, yaitu mengenai sistem pembukuan/pencatatan yang kurang sistematis yang berdampak pada laporan keuangan yang kurang akuntabel.

Tujuan penyusunan laporan keuangan adalah menyediakan informasi posisi keuangan dan kinerja keuangan suatu entitas yang bermanfaat bagi sejumlah besar pengguna dalam pengambilan keputusan ekonomi [4]. Walaupun UMKM merupakan entitas yang tidak memiliki atau minim akuntabilitas publik, penyusunan laporan keuangan yang akuntabel bukan merupakan suatu hal yang seharusnya dapat dikompromikan. Apabila sistem pembukuan tidak berjalan dengan baik, atau bahkan transaksi-transaksi ekonomi tidak secara rutin dicatat, maka hal ini akan berdampak pada penyajian informasi yang misleading [5]. Penyajian informasi yang tidak tepat sasaran menyebabkan keputusan yang diambil oleh perusahaan tidak sesuai atau tidak mendukung strategi dan tujuan yang ditetapkan perusahaan sebelumnya. Selain itu, penyajian informasi yang tidak tepat sasaran menyebabkan utilisasi aset perusahaan kurang optimal [6]. Konsekuensikonsekuensi tersebut seharusnya menjadi pertimbangan UMKM dalam memetakan kompetensi sumber daya manusia atau personel. Walaupun skala pertanggungjawaban masih minimal, potensi dampak internal yang ditimbulkan dapat menyebabkan perlambatan pertumbuhan perusahaan.

Permasalahan umum yang telah diuraikan di atas juga menjadi permasalahan spesifik pada institusi mitra. Berdasarkan identifikasi permasalahan umum dan permasalahan khusus yang dihadapi institusi mitra, kegiatan pengabdian kepada masyarakat ini dilaksanakan dalam rangka meningkatkan kompetensi sumber daya manusia atau secara spesifik pengembangan kompetensi personel yang ada di bagian akuntansi, keuangan, dan perpajakan. Peningkatan dan pengembangan kompetensi personel bidang keuangan difokuskan pada peningkatan kemampuan pembukuan serta penyusunan laporan keuangan entitas. Dosen pengabdi mengidentifikasi beberapa permasalahan yang dihadapi oleh institusi mitra, sebagai berikut:

- Permasalahan pertama yang dihadapi oleh institusi mitra adalah rendahnya kompetensi personel di bidang akuntansi, keuangan, dan perpajakan. Personel yang ditugaskan untuk bekerja pada bidang ini tidak memiliki latar belakang pendidikan akuntansi formal. Hal ini menyebabkan sistem pencatatan transaksi-transaksi ekonomi perusahaan kurang sistematis dan komprehensif. Laporan keuangan juga tidak dibuat secara berkala dan tidak didahului dengan sistem pembukuan yang kronologis.

- Permasalahan kedua yang dihadapi oleh institusi mitra adalah kurangnya pemanfaatan teknologi informasi untuk membantu proses administrasi pembukuan dan penyusunan laporan keuangan. Hal ini berpotensi menjadi masalah yang berkelanjutan karena di tahun-tahun yang akan datang - seiring dengan peningkatan omset dan volume transaksi perusahaan - personel akan semakin kesulitan dalam mencatat transaksi ekonomi secara kronologis, serta dalam penyusunan laporan keuangan. Hal ini juga akan mempersulit apabila perusahaan harus melakukan rekonsiliasi fiskal untuk kepentingan pelaporan SPT Tahunan.

- Permasalahan ketiga yang dihadapi oleh institusi mitra adalah tidak adanya pemisahan tugas antara bendahara dan personel pembukuan. Potensi dampak yang dapat timbul adalah adanya pengeluaran (cash disbursement) yang tidak tercatat, dan berakibat pada laporan posisi keuangan yang tidak seimbang. 


\section{TARGET DAN TUJUAN PENDAMPINGAN}

Target yang dibuat dalam pendampingan ini adalah sebagai berikut:

- Peningkatan kompetensi prinsip-prinsip dasar akuntansi (persamaan dasar akuntansi, siklus akuntansi, penyusunan laporan keuangan),

- Peningkatan kompetensi pemanfaatan teknologi informasi yang menunjang kompetensi dan efektivitas penyusunan laporan keuangan dan administrasi pembukuan institusi mitra. Teknologi informasi yang dimaksud dalam konteks program pengabdian ini adalah penggunaan perangkat lunak umum (contoh: Microsoft Excel) sebagai media otomatisasi pencatatan transaksi, bukan hanya sebagai media untuk mencatat transaksi tanpa memanfaatkan logika matematika.

- Peningkatan pemahaman tentang sistem pengendalian internal yang sederhana dan relevan dengan perusahaan berskala UMKM.

Pelatihan dalam rangka kompetensi ditujukan pada staf akuntansi, keuangan, dan perpajakan yang berjumlah 2 orang. Pembelajaran dan pelatihan kompetensi teknis akuntansi akan diberikan dengan metode transfer knowledge dan project-based learning.

Berikut merupakan rincian target perkembangan kegiatan PkM:

TABEL I

Target Perkembangan Program Pengembangan Kompetensi AKUNTANSI PT QEP

\begin{tabular}{|c|c|c|c|}
\hline \multirow[t]{2}{*}{ No } & \multicolumn{3}{|c|}{ Kondisi } \\
\hline & Sebelum PkM & Solusi & Setelah PkM \\
\hline 1 & $\begin{array}{l}\text { Belum memiliki } \\
\text { pengetahuan } \\
\text { mengenai prinsip- } \\
\text { prinsip dasar } \\
\text { akuntansi. }\end{array}$ & $\begin{array}{l}\text { Transfer } \\
\text { knowledge, } \\
\text { PjBL. }\end{array}$ & $\begin{array}{l}\text { Mengalami } \\
\text { peningkatan } \\
\text { literasi prinsip- } \\
\text { prinsip akuntansi. }\end{array}$ \\
\hline 2 & $\begin{array}{l}\text { Belum memiliki } \\
\text { pengetahuan } \\
\text { terstruktur mengenai } \\
\text { siklus akuntansi. } \\
\text { Perlu peningkatan } \\
\text { skill teknis terkait } \\
\text { dengan penyusunan } \\
\text { siklus akuntansi. }\end{array}$ & $\begin{array}{l}\text { Transfer } \\
\text { knowledge, } \\
\text { PjBL. }\end{array}$ & $\begin{array}{l}\text { Mengalami } \\
\text { peningkatan } \\
\text { literasi siklus } \\
\text { akuntansi serta } \\
\text { skill teknis } \\
\text { pembukuan. }\end{array}$ \\
\hline 3 & $\begin{array}{l}\text { Perlu peningkatan } \\
\text { skill pemanfaatan } \\
\text { teknologi informasi } \\
\text { yang mendukung } \\
\text { proses penyusunan } \\
\text { laporan keuangan. }\end{array}$ & $\begin{array}{l}\text { Transfer } \\
\text { knowledge, } \\
\text { PjBL }\end{array}$ & $\begin{array}{l}\text { Mengalami } \\
\text { peningkatan skill } \\
\text { terkait dengan } \\
\text { pemanfaatan } \\
\text { teknologi } \\
\text { informasi yang } \\
\text { mendukung } \\
\text { penyusunan } \\
\text { laporan keuangan. }\end{array}$ \\
\hline 4 & $\begin{array}{l}\text { Perlu peningkatan } \\
\text { literasi perpajakan } \\
\text { UMKM. }\end{array}$ & $\begin{array}{l}\text { Transfer } \\
\text { knowledge, } \\
\text { PjBL }\end{array}$ & $\begin{array}{l}\text { Mengalami } \\
\text { peningkatan } \\
\text { literasi perpajakan } \\
\text { UMKM serta }\end{array}$ \\
\hline
\end{tabular}

\begin{tabular}{|l|l|l|l|}
\hline & Perlu peningkatan & & penerapan sistem \\
& literasi sistem & & pengendalian \\
& pengendalian internal & & internal yang \\
& sederhana. & relevan dengan \\
& & operasional \\
perusahaan.
\end{tabular}

- Meningkatkan literasi prinsip-prinsip dasar akuntansi serta siklus akuntansi bagi personel PT Quantum Edukasindo Paradigma. Pengabdi menargetkan adanya peningkatan literasi secara bertahap oleh personel pada divisi akuntansi, keuangan, dan perpajakan. Prinsip-prinsip dasar akuntansi mencakup definisi, manfaat, serta logika di balik perlunya melakukan kegiatan pembukuan yang sistematis. Siklus akuntansi mencakup tahapantahapan yang diperlukan dalam proses pencatatan transaksi-transaksi ekonomi yang bermuara pada penyusunan laporan keuangan dengan data yang reliable dan kronologis.

- Meningkatkan kompetensi teknis personel dalam bidang ilmu akuntansi, yang secara spesifik diwujudkan dalam bentuk kemampuan teknis dalam menyelesaikan siklus akuntansi serta menyusun laporan keuangan sederhana.

- Meningkatkan pemahaman mengenai pemanfaatan teknologi informasi yang menunjang proses pelaporan dan administrasi perpajakan. Program pengabdian periode ini tidak menargetkan penguasaan teknologi informasi yang mumpuni dan mahir, karena proses tesebut berkesinambungan, membutuhkan pengulangan. Harapannya, dengan program pengabdian ini, institusi mitra mengalami peningkatan daya analisa dengan pemahaman mengenai logika matematika yang dapat dimanfaatkan untuk mempermudah proses pembukuan dan pelaporan laporan keuangan. Logika matematika ini juga bisa digunakan sebagai media automatisasi transaksi serta bentuk pengendalian untuk menjaga akurasi perhitungan.

- Meningkatkan pemahaman institusi mitra mengenai peraturan-peraturan pajak terbaru, terutama yang berhubungan dengan insentif yang diberikan pemerintah selama masa pandemi kepada UMKM. Selain itu, pengabdi juga bertujuan untuk memberikan wawasan mengenai kewajiban perpajakan yang mungkin timbul di masa depan, apabila perusahaan sudah mengalami peningkatan kapasitas usaha.

- Meningkatkan pemahaman institusi mitra mengenai pentingnya sistem pengendalian internal pada perusahaan.

- Melalui program pengabdian kepada masyarakat dalam bentuk pendampingan dan peningkatan literasi, diharapkan terjadinya peningkatan kualitas 
sumber daya manusia pada institusi mitra. Di masa yang akan datang, ketika perekonomian perusahaan semakin berkembang, institusi mitra sudah lebih siap dengan sistem pembukuan yang kronologis dan sistematis serta sudah memahami kewajiban perpajakan yang akan mengikuti. Selain itu, program pengabdian ini juga bertujuan meningkatkan kesadaran untuk memiliki sikap transparan kepada pemerintah dan kepada semua stakeholder yang ada di lingkungan bisnis institusi mitra.

\section{MEtode PELAKSANAAN}

\section{A. Persoalan Prioritas Mitra}

Persoalan prioritas yang diangkat dalam penelitian ini adalah kurangnya kemampuan teknis staf perusahaan dalam membuat dan menyelesaikan siklus akuntansi serta menyusun laporan keuangan. Hal ini ditunjukkan dengan tidak adanya catatan transaksi yang kronologis dan sistematis, serta tidak adanya laporan keuangan perusahaan yang sesuai dengan kaidah-kaidah yang diatur dalam standar yang relevan. Standar yang relevan dan dijadikan landasan pelatihan penyusunan laporan keuangan adalah Standar Akuntansi Keuangan Entitas Tanpa Akuntabilitas Publik (SAK ETAP).

\section{B. Metode Pelaksanaan}

\section{1) Prinsip Pengabdian kepada Masyarakat}

Human Development atau pembangunan manusia menurut United Nations Development Programme (UNDP) adalah tentang "expanding the richness of human life", dan bukan hanya sekedar mengembangkan kekayaan ekonomi yang ada dalam hidup seorang individu. UNDP memaparkan dalam rencana strategis 5 tahun ke depan, bahwa salah satu arah perubahan yang dicanangkan adalah empowerement, inclusion, human agency, dan human development [7]. Prinsip-prinsip ini menjadi dasar bagi setiap proses perbaikan dan peningkatan kompetensi individu maupun organisasi-organisasi, tak terkecuali organisasi bisnis.

Pembangunan manusia merupakan sebuah pendekatan yang memiliki fokus pada manusia serta peluang dan pilihan yang dibuatnya. Pembangunan manusia memiliki inti perkembangan pada hidup manusia, tidak hanya berasumsi bahwa pertumbuhan ekonomi pada hidup individu akan serta merta meningkatkan kualitas kesejahteraan hidup (well-being) secara keseluruhan [8]. Pembangunan manusia menitikberatkan pada kemampuan individu untuk menjadi adaptif dengan lingkungan yang selalu dinamis dan resilien dalam menghadapi risiko dan tantangan.

Peluang yang dimaksud pada proses pembangunan manusia adalah memberikan kebebasan pada setiap individu untuk menemukan nilai-nilai kehidupan yang diyakini. Tiga pondasi dalam hidup manusia terkait dengan 1) kesehatan dan harapan hidup yang panjang, 2) memiliki pengetahuan yang lebih luas, serta 3) memiliki akses pada sumber daya yang diperlukan untuk meningkatkan kualitas hidup masing-masing individu. Ketiga pondasi tersebut bisa terproyeksi dalam berbagai bidang kehidupan individu.

Pilihan/choice dalam pembangunan manusia adalah mengenai menyediakan peluang-peluang bagi individu untuk diakses dan dimanfaatkan, bukan memaksa individu untuk memilih satu diantara yang lain, dilandasi dengan perspektif orang lain. Ketiga prinsip ini menjadi kerangka pelaksanaan program Pengabdian kepada Masyarakat.

\section{2) Metode Pelaksanaan Pengabdian kepada Masyarakat}

Program pengabdian kepada masyarakat memfokuskan masyarakat sebagai poros penentu perkembangan komunitas, atau dalam konteks program pengabdian ini poros perkembangan institusi. Mardikanto \& Soebianto [9] memandang pengabdian sebagai proses. Institusi mitra difasilitasi untuk menganalisa permasalahan dan kebutuhan secara mandiri, dengan didorong oleh dosen pengabdi. Paradigma yang dibangun dalam pelaksanaan program pengabdian kepada masyarakat adalah pengabdian yang sifatnya partisipatoris dengan mengedepankan pengembangan kompetensi mitra.

Secara spesifik, metode pelaksanaan program pengabdian kepada masyarakat dilandasi dengan paradigma Participatory Action Learning and Action Research (PALAR). PALAR [10] merupakan kerangka teori, kerangka edukasi, dan kerangka metodologi yang digunakan untuk pengembangan individu, profesional, organisasi, maupun komunitas. PALAR merupakan pengembangan dari teori action learning (PLA) dan teori participatory action research (PAR), yang menghasilkan suatu kerangka pengembangan organisasi yang komprehensif.

Selain action learning dan action research, PALAR juga mengusung ide lifelong learning [11]. Lifelong learning tidak hanya berfokus pada jangka waktu pembelajaran yang kita jalani sepanjang hidup, tetapi esensi dari bagaimana kita menjadi pembelajar-pembelajar seumur hidup. Belajar terus menerus secara sadar dan terarah merupakan inti dari lifelong learning. Pembelajaran secara terus menerus dan terarah dioperasionalkan dalam rupa kompetensi yang penting dimiliki oleh seorang lifelong-learner. Pada abad 21 , beberapa kompetensi yang penting dan relevan untuk dikembangkan adalah kemampuan berpikir kritis serta pemecahan masalah, komunikasi, kreativitas, serta inovasi.

Program pengembangan sumber daya manusia dalam proses pengabdian kepada masyarakat juga memiliki fokus untuk mengembangkan kompetensi berpikir kritis serta pemecahan masalah organisasi secara mandiri. Dorongan untuk memiliki kompetensi problem-solver merupakan salah satu proses belajar secara partisipatif dan berdasarkan 
pengalaman nyata (learning by doing) - yang merupakan ide utama PAR dan PLA.

Menurut Mardikanto \& Soebianto [9], manfaat yang diperoleh melalui kegiatan pengabdian berbasis PLA adalah:

- Menjawab permasalahan internal organisasi yang mungkin tidak dapat dijawab oleh pihak luar organisasi - dalam konteks program pengabdian kepada masyarakat ini dosen pengabdi merupakan pihak luar organisasi.

- Karyawan institusi mitra akan memeroleh banyak pengetahuan yang berbasis pengalaman - dalam konteks program pengabdian kepada masyarakat ini adalah pengalaman untuk menyusun laporan keuangan perusahaan dengan segala keterbatasan dan permasalahan.

- Karyawan institusi mitra akan mengalami proses pemecahan solusi atas permasalahan internal secara mandiri - bukan dosen pengabdi yang memecahkan masalah organisasi.

- Pihak luar dapat menjadi penghubung antara institusi mitra dengan lembaga lain yang diperlukan - dalam konteks program pengabdian kepada masyarakat ini, dosen pengabdi dapat menjadi penghubung dengan kantor pelayanan pajak.

Dalam prosesnya, dosen pengabdi sebagai fasilitator tidak memiliki hubungan yang bersifat vertikal, tetapi horizontal atau setara.

Proses identifikasi masalah yang dilakukan merupakan langkah awal yang sesuai dengan konsep PALAR. Proses masuk dalam komunitas harus diawali dengan negosiasi, dan formulasi rangkaian action learning. Inisiatif dari institusi mitra harus diutamakan dan difasilitasi dengan baik supaya tercipta visi yang kolaboratif. Proses pendampingan ini juga harus sangat spesifik tergantung dari kapasitas dan kebutuhan organisasi mitra. Berikut merupakan bagan konsep PALAR yang diturunkan dari Zuber-Skeritt [12]:

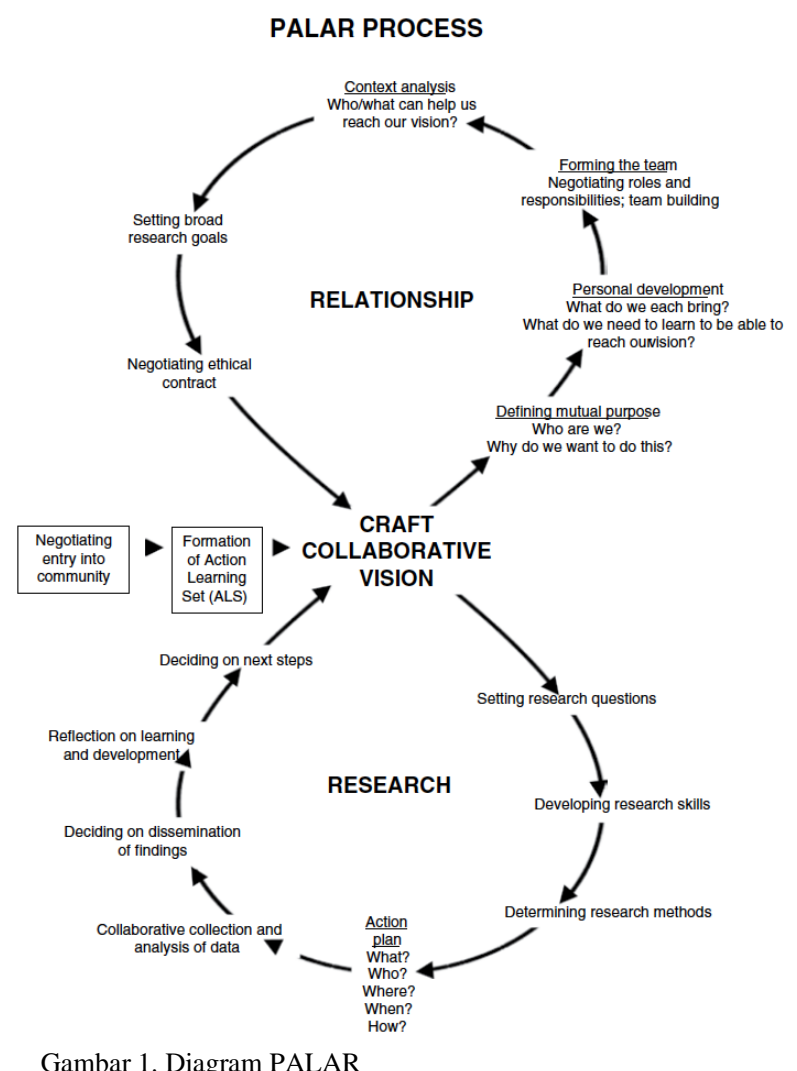

3) Tahapan Pelaksanaan Pengabdian

Penyusunan rencana tahapan/langkah-langkah pelaksanaan pengbadian disusun berdasarkan PALAR dan yang juga sejalan dengan tahapan yang dirancang [13] secara lebih sederhana. Tahapan pelaksanaan pengabdian dimulai dengan mengidentifikasi beberapa hal yang didukung dengan kerangka pertanyaan sebagai berikut:

- Who is involved in this work?

- Where the work occurs?

- What do we each bring?

- How the work is conducted?

- What is the outcome or desired results are from work?

Who is involved in this work? Pengabdian masyarakat ini melibatkan dosen pengabdi, Rossalina Christanti sebagai akademisi yang bekerja sebagai dosen Fakultas Bisnis Universitas Kristen Duta Wacana Yogyakarta untuk membantu perusahaan menyusun laporan keuangan yang akuntabel dan kredibel. Pengabdian masyarakat ini juga melibatkan PT QEP sebagai institusi mitra, yang memerlukan pendampingan dalam rangka pengembangan kompetensi sumber daya manusia, baik dari sisi teoritis maupun teknis. Personel PT QEP yang terlibat langsung dalam pengabdian ini adalah dua orang pegawai administrasi pembukuan yang merangkap bendahara dan administrasi perpajakan. Kegiatan pengabdian ini berada di 
bawah payung institusi Universitas Kristen Duta Wacana sebagai institusi pendidikan yang mengemban tugas Tri Dharma Perguruan Tinggi.

Where the work occurs? Kegiatan pengabdian kepada masyarakat dilakukan secara daring melalui kanal Zoom.

What do we each bring? Dosen sebagai fasilitator membawa latar belakang ilmu akuntansi dan pengalaman bekerja di bidang akuntansi dan perpajakan. Karyawan institusi mitra membawa latar belakang pengetahuan, pengalaman, proses organisasi mitra yang memiliki ciri khas.

How the work is conducted? Kegiatan pengabdian kepada masyarakat ini dilakukan dalam bentuk pendampingan semi-intensif. Pendampingan ini dilakukan dengan metode transfer knowledge dan workshop yang dilakukan dengan metode project-based learning, dengan staf yang bertanggung jawab untuk mencatat transaksi ekonomi sehari-hari, mengeluarkan dan menyetorkan kas di bank, serta melengkapi administrasi perpajakan. Pemberian penyuluhan dan tutorial dilakukan satu bulan satu-dua kali pertemuan secara daring melalui kanal Zoom. Pendampingan juga dilakukan melalui media komunikasi (telepon dan whatsapp) apabila institusi mitra memiliki pertanyaan saat jeda waktu penyuluhan.

What is the outcome or desired results are from work? Melalui kegiatan pengabdian kepada masyarakat ini, outcome atau hasil yang diharapkan dari pendampingan PT QEP adalah sebagai berikut:

- Peningkatan kemampuan teknis mencatat transaksi ekonomi dalam bentuk jurnal akuntansi, penyelesaian siklus akuntansi, serta penyusunan laporan keuangan berbasis SAK ETAP.

- Peningkatan literasi teknologi informasi yang menunjang proses administrasi pembukuan dan penyusunan laporan keuangan.

- Peningkatan literasi administrasi perpajakan UMKM.

- Peningkatan literasi sistem pengendalian internal.

Berdasarkan kerangka metodologi yang sudah ditetapkan beserta analisa-analisa pertanyaan yang dijadikan sebagai acuan, organisasi mitra beserta dengan fasilitator bersamasama merancang strategi pendampingan yang efektif dan sesuai dengan prinsip-prinsip yang sudah ditentukan.

Peningkatan kemampuan teknis mencatat transaksi ekonomi ke dalam jurnal akuntansi dan memrosesnya hingga tersusun laporan keuangan dapat langsung dilakukan dengan menggunakan transaksi-transaksi ekonomi institusi mitra. Hal ini ditujukan agar proses pendampingan dapat tepat sasaran dan kontekstual. Tentu saja, sebelumnya fasilitator memberikan transfer pengetahuan akuntansi dasar secara umum. Pada akhir pendampingan, harapannya karyawan bagian akuntansi dan perpajakan sudah dapat menyusun laporan keuangan institusi mitra secara mandiri.

\section{HASIL YANG DICAPAI}

Reflection on learning and development merupakan tahapan menganalisa hasil pendampingan atau pembelajaran yang dilakukan berdasarkan institusi mitra. Idealnya, hasil dari suatu proses pembelajaran adalah peningkatan kompetensi sumber daya manusia yang disertai dengan kemandirian dalam menyelesaikan permasalahan internal institusi.

Di dalam ilmu manajemen, terdapat 3 aktifitas utama yang menunjang proses operasional organsisasi, yaitu 1) perencanaan, 2) pengendalian, dan 3) pengambilan keputusan. Proses perencanaan merupakan tahapan penetapan tujuan yang diuraikan menjadi indentifikasi tahapan-tahapan untuk mencapai tujuan yang terlebih dahulu ditetapkan. Pengendalian merupakan proses evaluasi dengan membandingkan kinerja aktual dengan tahapantahapan yang sudah ditetapkan. Pengambilan keputusan merupakan langkah mengambil tindakan korektif dan tindak lanjut atas hasil evaluasi.

Program pengabdian kepada masyarakat ini memiliki tujuan mengembangkan kompetensi sumber daya manusia bidang akuntansi dan perpajakan. Pengembangan kompetensi dapat dioperasionalkan menjadi peningkatan skill atau kompetensi di bidang akuntansi dan perpajakan. Secara spesifik, subjek yang disasar adalah staff akuntansi PT QEP. Langkah-langkah untuk mencapai tujuan tersebut tercermin dalam jadwal pendampingan sebagai berikut:

TABEL II

JADWAL PENDAMPINGAN

\begin{tabular}{|c|c|c|}
\hline $\begin{array}{c}\text { Meeting } \\
\text { Ke- }\end{array}$ & Waktu & Aktivitas/Materi \\
\hline 1 & $\begin{array}{l}\text { Jumat, } \\
5 / 2 / 21\end{array}$ & $\begin{array}{l}\text { Dasar-Dasar Akuntansi } \\
\text { - Pengertian Akuntansi \& } \\
\text { Lingkup Pelaporan Informasi } \\
\text { Keuangan } \\
\text { - Persamaan Dasar Akuntansi } \\
\text { - Debet/Kredit }\end{array}$ \\
\hline $2-5$ & $\begin{array}{l}\text { Sabtu, } \\
6 / 3 / 21 \\
\text { Jumat, } \\
12 / 321 \\
\text { Sabtu, } \\
3 / 4 / 21 \\
\text { Jumat, } \\
9 / 4 / 21\end{array}$ & $\begin{array}{l}\text { Menyusun Siklus Akuntansi } \\
\text { - Jurnal Umum } \\
\text { - Buku Besar } \\
\text { - Neraca Saldo }\end{array}$ \\
\hline $6-7$ & $\begin{array}{l}\text { Sabtu, } \\
8 / 5 / 21, \\
\text { Jumat, } \\
4 / 6 / 21\end{array}$ & $\begin{array}{l}\text { Menyelesaikan Siklus } \\
\text { Akuntansi } \\
\text { - Jurnal Penyesuaian } \\
\text { - Neraca Saldo Setelah } \\
\text { Penyesuaian } \\
\text { - Jurnal penutup } \\
\text { - Neraca Lajur } \\
\end{array}$ \\
\hline $8-10$ & $\begin{array}{l}\text { Sabtu, } \\
12 / 6 / 21 \\
\text { Jumat, } \\
\text { 2/7/21, }\end{array}$ & $\begin{array}{l}\text { Menyusun Laporan Keuangan } \\
\text { - Laporan Laba Rugi } \\
\text { - Laporan Perubahan Modal } \\
\text { - Laporan Posisi Keuangan }\end{array}$ \\
\hline
\end{tabular}




\begin{tabular}{|l|l|l|}
\hline & Sabtu, & - Laporan Arus Kas \\
& $10 / 7 / 21$ & \\
\hline $11-12$ & Sabtu, & Perpajakan UMKM \\
& $7 / 8 / 21$, & \\
& Sabtu, & \\
& $21 / 8 / 21$ & \\
\hline 13 & Senin, & Sistem Pengendalian Internal \\
& $6 / 9 / 21$ & \\
\hline
\end{tabular}

Evaluasi [9] dapat dimaknai sebagai kegiatan terencana dan sistematis yang meliputi: 1) pengamatan untuk pengumpulan data dan fakta, 2) penggunaan "pedoman" yang telah ditetapkan, 3) pengukuran atau perbandingan hasil pengamatan dengan pedoman-pedoman yang sudah terlebih dahulu ditetapkan, dan 4) penilaian dan pengambilan keputusan. Evaluasi juga dilakukan untuk mengidentifikasi dampak atau impact bagi institusi mitra [14].

Evaluasi dalam program ini dilakukan secara kualitatif dan kuantitatif. Evaluasi kualitatif dilakukan dengan analisa single before-after program pengabdian kepada masyarakat. Evaluasi kuantitatif dilakukan dengan pengisian kuesioner evaluasi dan kepuasan institusi mitra kepada fasilitator. Evaluasi dilakukan setelah program pendampingan berakhir.

Berikut merupakan hasil analisa kualitatif program pengabdian kepada masyarakat:

TABEL II

ANALISA Single BEFORE-AFTER PROGRAM PKM

\begin{tabular}{|c|c|c|c|}
\hline No & Target & $\begin{array}{c}\text { Sebelum } \\
\text { Pendampingan }\end{array}$ & $\begin{array}{c}\text { Setelah } \\
\text { Pendampingan }\end{array}$ \\
\hline 1. & $\begin{array}{l}\text { Kompetensi } \\
\text { mencatat } \\
\text { transaksi } \\
\text { ekonomi ke } \\
\text { dalam jurnal } \\
\text { akuntansi dan } \\
\text { menyelesaikan } \\
\text { siklus } \\
\text { akuntansi }\end{array}$ & $\begin{array}{ll}\text { - } & \text { Belum memiliki } \\
\text { pemahaman } \\
\text { akuntansi. } \\
\text { - Belum dapat } \\
\text { menyusun } \\
\text { jurnal akuntansi } \\
\text { - } \text { Belum dapat } \\
\text { menyelesaikan } \\
\text { siklus akuntansi }\end{array}$ & $\begin{array}{l}\text { - Sudah dapat } \\
\text { menjelaskan } \\
\text { tahapan- } \\
\text { tahapan dalam } \\
\text { siklus akuntansi } \\
\text { - Sudah dapat } \\
\text { menjurnal } \\
\text { transaksi } \\
\text { ekonomi secara } \\
\text { mandiri } \\
\text { - Sudah dapat } \\
\text { menyelesaikan } \\
\text { siklus akuntansi } \\
\text { tetapi masih } \\
\text { harus dilakukan } \\
\text { di bawah } \\
\text { pendampingan }\end{array}$ \\
\hline 2. & $\begin{array}{l}\text { Peningkatan } \\
\text { literasi } \\
\text { teknologi } \\
\text { informasi } \\
\text { penunjang } \\
\text { pencatatan } \\
\text { akuntansi } \\
\end{array}$ & $\begin{array}{l}\text { Belum } \\
\text { menggunakan } \\
\text { Ms.Excel sebagai } \\
\text { media pencatatan } \\
\text { akuntansi }\end{array}$ & $\begin{array}{l}\text { Sudah memakai } \\
\text { kertas kerja yang } \\
\text { disediakan peneliti } \\
\text { dalam menjurnal } \\
\text { dan } \\
\text { menyelesaikan } \\
\text { siklus akuntansi. }\end{array}$ \\
\hline
\end{tabular}

\begin{tabular}{|c|c|c|c|}
\hline 3. & $\begin{array}{l}\text { Peningkatan } \\
\text { literasi } \\
\text { perpajakan } \\
\text { UMKM }\end{array}$ & $\begin{array}{l}\text { Sudah memahami } \\
\text { kewajiban } \\
\text { perpajakan } \\
\text { UMKM, tetapi } \\
\text { belum } \\
\text { memanfaatkan } \\
\text { insentif } \\
\text { perpajakan selama } \\
\text { pandemi. }\end{array}$ & $\begin{array}{l}\text { Sudah } \\
\text { memanfaatkan } \\
\text { insentif } \\
\text { perpajakan selama } \\
\text { pandemi. }\end{array}$ \\
\hline 4. & $\begin{array}{l}\text { Peningkatan } \\
\text { literasi sistem } \\
\text { pengendalian } \\
\text { internal } \\
\text { organisasi. }\end{array}$ & $\begin{array}{l}\text { Belum memiliki } \\
\text { pemahaman } \\
\text { tentang sistem } \\
\text { pengendalian } \\
\text { internal. }\end{array}$ & $\begin{array}{l}\text { Sudah dapat } \\
\text { menjelaskan } \\
\text { sistem } \\
\text { pengendalian } \\
\text { internal sederhana } \\
\text { yang dapat } \\
\text { diterapkan di } \\
\text { organisasi. } \\
\text { Contoh: } \\
\text { penggunaan } \\
\text { dokumen pre- } \\
\text { numbered, proses } \\
\text { otentifikasi } \\
\text { pengeluaran kas, } \\
\text { pembagian tugas, } \\
\text { menjaga } \\
\text { keamanan aset } \\
\text { secara fisik. }\end{array}$ \\
\hline
\end{tabular}

Evaluasi kuantitatif dilakukan dengan menyebarkan kuesioner elektronik untuk menilai kinerja fasilitator. Berikut merupakan tampilan hasil kuesioner yang diisi oleh karyawan institusi mitra yang mengikuti pendampingan.

Seberapa puas Bp./Ibu terhadap respon kami dalam proses penyusunan rencana pembelajaran akuntansi bersama PT QEP?

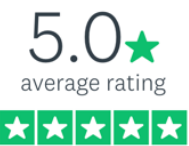

Gambar 2. Pertanyaan 1 Kuesioner

Seberapa puaskah Bapak/Ibu terhadap tim dosen dalam memfasilitasi proses penyelenggaraan pendampingan pembelajaran akuntansi bersama PT QEP? Answered: 1 skipped: 0

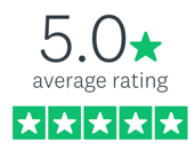

Gambar 3. Pertanyaan 2 Kuesioner

Seberapa puaskah Bapak/Ibu terhadap kesesuaian rencana pembelajaran dengan implementasi rencana tersebut?

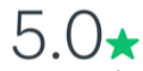

average rating 
Gambar 4. Pertanyaan 3 Kuesioner

Seberapa puaskah Bapak/Ibu terhadap kompetensi dosen/fasilitator dalam memberikan pendampingan pembelajaran akuntansi kepada PT QEP? Answered : 1 Skipped: 0

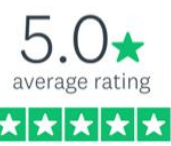

Gambar 5. Pertanyaan 4 Kuesioner

Kritik \& Saran:

Answered: 1 skipped: 0

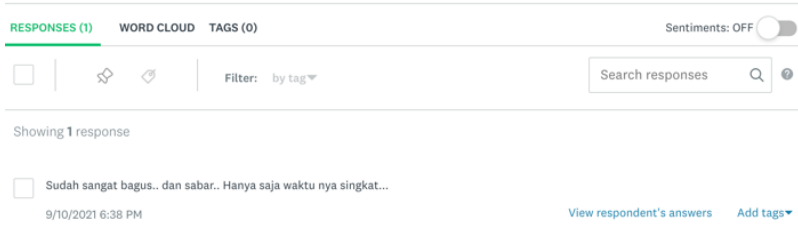

Gambar 6. Pertanyaan 5 Kuesioner

Evaluasi kualitatif dilakukan oleh fasilitator, sedangkan evaluasi kuantitatif dilakukan oleh mitra, sehingga diharapkan dapat terakumulasi hasil yang objektif.

\section{Keberlanjutan Program Dan RENCANa TAHAPAN SELANJUTNYA}

Fakultas Bisnis Universitas Kristen Duta Wacana memberikan dukungan penuh untuk memastikan bahwa mitra yang didampingi dapat berkembang sesuai dengan fase dan kebutuhan organisasi, bahkan setelah periode pendampingan berakhir. Rencana tahapan selanjutnya adalah melakukan pendampingan informal, khususnya untuk meningkatkan kemandirian dalam menyusun format laporan keuangan baku perusahaan. Meskipun pendampingan yang dilakukan tidak lagi berupa pendampigan intensif, tetapi dosen pengabdi dan institusi pendidikan pendukung tetap berkomitmen untuk tetap menjalankan hubungan yang baik.

Pendampingan yang bersifat insidental juga dapat dilakukan apabila di kemudian hari muncul isu-isu baru, khususnya terkait dengan peraturan perpajakan yang dinamis dan selalu berkembang mengikuti kebutuhan dan dinamika perekonomian nasional. Tax Center UKDW merupakan salah satu unit yang bisa bekerja sama dalam mendampingi institusi mitra dalam bidang perpajakan.

\section{KESIMPULAN}

Program pengabdian kepada masyarakat dilakukan dengan tujuan meningkatkan kompetensi sumber daya manusia dalam perusahaan mitra, khususnya di bidang akuntansi dan perpajakan. Institusi mitra pada program pengabdian kepada masyarakat ini adalah PT Quantum
Edukasindo Paradigma, perusahaan yang bergerak di bidang jasa psikodiagnostika.

Peningkatan literasi dan kompetensi akuntansi perusahaan jasa diberikan melalui program pendampingan dengan metode project-based learning. Fasilitator memberikan transfer pengetahuan terkait dengan dasardasar akuntansi perusahaan jasa serta dasar-dasar perpajakan untuk usaha skala mikro, kecil, dan menengah.

Menggunakan transaksi riil perusahaan, fasilitator mendampingi karyawan divisi akuntansi untuk bersamasama menyusun catatan akuntansi yang lengkap hingga dapat menyusun laporan keuangan. Selain itu, institusi mitra juga berkonsultasi terkait dengan isu-isu perpajakan UMKM dan sistem pengendalian internal organisasi.

Hasilnya, karyawan divisi akuntansi yang mengikuti program pendampingan ini sudah dapat menyusun catatancatatan akuntansi, dalam bentuk jurnal, buku besar, neraca lajur, jurnal penyesuaian, neraca lajur setelah penyesuaian, hingga jurnal penutup. Namun demikian, untuk menyusun laporan keuangan, masih diperlukan pendampingan intensif.

Secara umum, program pengabdian kepada masyarakat sudah dapat mencapai target yang ditetapkan, yaitu peningkatan skill atau kompetensi di bidang akuntansi dan perpajakan.

\section{UCAPAN TERIMA KASIH}

Penulis mengucapkan terima kasih kepada Fakultas Bisnis Universitas Kristen Duta Wacana untuk setiap dukungan yang diberikan sehingga kegiatan pengabdian ini dapat terlaksana dengan lancar. Penulis juga mengucapkan terima kasih kepada PT Quantum Edukasindo Paradigma yang bersedia mengikuti program pendampingan ini. Akhirnya, penulis mengucapkan terima kasih kepada LPPM UKDW yang memfasilitasi diseminasi program pengabdian kepada masyarakat.

\section{DAFTAR PUSTAKA}

[1] D. Tarmidi, G. P. Solihati, A. Suryati, and P. N. Sari, "Sosialisasi \& Pelatihan Penghitungan \& Penyetoran Pajak Bagi UMKM,” Din. J. Pengabdi. Kpd. Masy., vol. 5, no. 3, pp 1-8, 2021, doi: 10.31849/dinamisia.v5i3.4109.

[2] K. Sedyastuti, "Analisis Pemberdayaan UMKM Dan Peningkatan Daya Saing Dalam Kancah Pasar Global,” INOBIS J. Inov. Bisnis dan Manaj. Indones., vol. 2, no. 1, pp. 117-127, 2018, doi: 10.31842/jurnal-inobis.v2i1.65.

[3] S. N. Wisnantiasri, I. P. Sofia, F. Nurhidayah, and K. Sunaryo, "Pelatihan Pembuatan Laporan Keuangan Bagi UMKM Sebagai Informasi Untuk Pengambilan Keputusan," $J$. Pemberdaya. Masy. madani, vol. 2, no. 1, pp. 63-82, 2018, doi: 10.30537/sjcms.v2i1.

[4] I. A. Indonesia, Standar Akuntansi Keuangan Entitas Tanpa Akuntabilitas Publik. Ikatan Akuntan Indonesia, 2019.

[5] M. B. Romney and P. J. Steinbart, Accounting Information System, 14th ed. New York: Pearson, 2018.

[6] D. Achjari, W. Abdillah, S. Suryaningsum, and S. Suratman, "Kesiapan Usaha Mikro, Kecil Dan Menengah Industri Kreatif Untuk Mengadopsi Teknologi Informasi," J. Akunt. dan Audit. Indones., vol. 15, no. 2, pp. 143-160, 2011, [Online]. 
Available: https://journal.uii.ac.id/JAAI/article/view/3748

[7] UNDP, "United Nations Development Programme Strategic

Plan 2022-2025," New York, 2021. doi: 10.1016/b978-0-44486236-5.50086-9.

[8] J. Hickel, "The sustainable development index: Measuring the ecological efficiency of human development in the anthropocene," Ecol. Econ., vol. 167, no. May 2019, p. 106331, 2020, doi: 10.1016/j.ecolecon.2019.05.011.

[9] T. Mardikanto and P. Soebianto, Pemberdayaan Masyarakat dalam Perspektif Kebijakan Publik. Bandung: ALFABETA, 2012.

[10] O. Zuber-Skerritt, "An educational framework for participatory action learning and action research (PALAR)," Educ. Action Res., vol. 26, no. 4, pp. 513-532, 2018, doi:

10.1080/09650792.2018.1464939.

[11] R. Setlhare and L. Wood, "A collaboratively constructed action leadership framework for sustainable learner support in contexts of adversity," Educ. Action Res., vol. 28, no. 2, pp. 227-241, 2020, doi: 10.1080/09650792.2018.1559070.

[12] L. Wood, "PALAR: Participatory Action Learning and Action Research for Community Engagement," Action Learn. Action Res. Genres Approaches, pp. 193-206, 2019, doi: 10.1108/9781-78769-537-520191017.

[13] A. Lathouras, "Development Community Work - A Method," in Community Development Practice Stories: Stories, Method, and Meaning, Australia: Common Ground Publishing Pty Ltd, 2011.

[14] P. J. Gertler, S. Martinez, P. Premand, L. B. Rawlings, and C. M. J. Vermeersch, Impact Evaluation. Washington DC, 2016. 